\title{
СОВЕРШЕНСТВОВАНИЕ УПРАВЛЕНИЯ ИННОВАЦИОННОЙ ДЕЯТЕЛЬНОСТЬЮ КОМПАНИЙ НЕФТЕГАЗОВОГО СЕКТОРА РЕСПУБЛИКИ КАЗАХСТАН
}

\author{
(c) 2020 Айтимова Диана Аксериковна \\ докторант 2-го курса, специальность «Инновационный менеджмент» \\ Казахский национальный университет имени аль-Фараби, Казахстан, Алматы \\ E-mail: diwka055@gmail.com \\ ORCID iD 0000-0003-4757-1321
}

\section{(C) 2020 Алибекова Гульназ Жанатовна}

доктор $\mathrm{PhD}$, директор департамента информации и коммерциализации

Институт экономики комитета науки Министерства науки и образования РК, Казахстан, Алматы

E-mail:g_alibekova@mail.ru

Возрастающий объём информации, необходимость её анализа, обработки и использования требует изменения концептуальных подходов к управлению предприятием. Современные тенденции развития мировой промышленности и цифровая трансформация экономики обуславливают необходимость совершенствования инновационного менеджмента, внедрения передовых производственных и IT - технологий, способствующих реализации задач оперативного управления инновационными процессами. Активная инновационная деятельность компаний нефтегазового сектора РК является технологической и финансовой основой формирования и реализации платформы для построения цифровой экономики РК в соответствии с глобальными трендами её развития.

В данной работе обосновано приоритетное направление индустриально-инновационного развития КНГС РК - совершенствование управления инновационной деятельностью на основе современных информационно-аналитических технологий с позиции ключевых принципов развития новой экономики: наращивания научного знания и инновационного потенциала. Проанализирована готовность предприятий НГС РК к инновационной реструктуризации предложена модель, способствующая совершенствованию процесса управления инновационной деятельностью, направленная на выявление резервов роста инновационной активности, повышение качества и эффективности инновационной деятельности и развитие инновационного, цифрового и конкурентного потенциалов. Отмечена важность создания благоприятных внешних условий для повышения результативности инновационной деятельности предприятий РК.

Ключевые слова: инновация, инновационная деятельность, конкурентоспособность, моделирование, развитие, управление.

\section{Введение}

Активизация инновационной деятельности компаний нефтегазового сектора Республики Казахстан на основе развития крупных наукоемких предприятий - необходимое условие роста эффективности и конкурентоспособности экономики в условиях глобализации и перехода к новому технологическому укладу, формирующемуся на базе знаний, прорывных информационно-аналитических технологий и креативных управленческих решений, поскольку этот сектор формирует финансовую основу бюджета Республики Казахстан.

Практикуемые в настоящее время инвестиции в воспроизводство и рост выпуска уста- ревшей продукции отбрасывают предприятия республики с позиций лидеров отраслей, способствуют росту изношенности основных фондов, снижению оборотности средств, спаду спроса на продукцию и необратимости отставания от высокотехнологичных международных корпораций.

Такая ситуация порождена состоянием отраслей, не обладающих достаточными средствами для технико-технологической модернизации, монетарным подходом руководства к совершенствованию организационно-производственной структуры, отсутствием стимулирования к активизации инновационной деятельности, следствием чего является отсутствие достаточного 
объема аналитических научно-обоснованных разработок и программ для решения управленческих задач по её совершенствованию.

Решение проблемы на данном этапе состоит в переходе к политике непрерывного опережающего развития на основе адаптации к тенденциям эволюционирования мировой экономики на основе совершенствования организационноуправленческой структуры компаний нефтегазового сектора (КНГС) и рационализации их инновационной деятельности (ИД), обуславливающих увеличение рыночного сегмента и рост конкурентоспособности.

Индустриально-инновационное развитие на современном этапе эволюционирования экономики рассматривается в Государственных программах РК, как приоритетное направление национальной государственной экономической политики. В «Послании Главы государства народу Казахстана» от 6 февраля 2008 года отмечается, что «только высокие технологии и инновации помогут избежать угрозы отставания государства в глобальной экономике».

Актуальность повышения конкурентоспособности РК на основе развития технологий и активизации инновационной деятельности, роста компетенций кадров на всех уровнях производственной иерархии, способствующая трансформации экономических структур в соответствии с глобальными трендами индустриального развития подчеркивается и в Стратегическом плане развития Республики Казахстан до 2025 года, который был утвержден Указом Президента Республики Казахстан № 636 от 15 февраля 2018 года.
В настоящее время производственные компании PK уступают зарубежным конкурентам по многим экономическим и организационноуправленческим показателям, что существенно затрудняет их выход на глобальный рынок, несмотря на имеющиеся предпосылки роста эффективности функционирования предприятий, наличие уникальной производственной и научной базы, господдержки и собственных средств для инвестиций в создание креативных секторов отрасли.

Высокая инновационная активность КНГС с акцентом на цифровые технологии катализирует положительную динамику их функционирования и обеспечивает рост рейтинга предприятий нефтегазовой отрасли РК среди аналогичных международных компаний.

Однако современная позиция Казахстана по уровню глобального инновационного индекса пока не отвечает задачам, поставленным правительством и ГПИИР (рис. 1).

Согласно статистическим данным IMD (Institute of Management Development) World Competitiveness Center (Швейцария) рейтинг РК среди 63 стран с наиболее развитой экономикой за период 2013 г.-2019 г. по основным показателям: конкурентоспособность, цифровая конкурентоспособность, знания, технологии, готовность к будущему и общему рейтингу (по совокупности факторов: талант, обучение и образование, научная концентрация, нормативно правовые основы, капитал, технологическая база, адаптивные качества, гибкость бизнеса, интеграция ИТ) имеет недостаточно высокий уровень для лидерства (рис. 2).

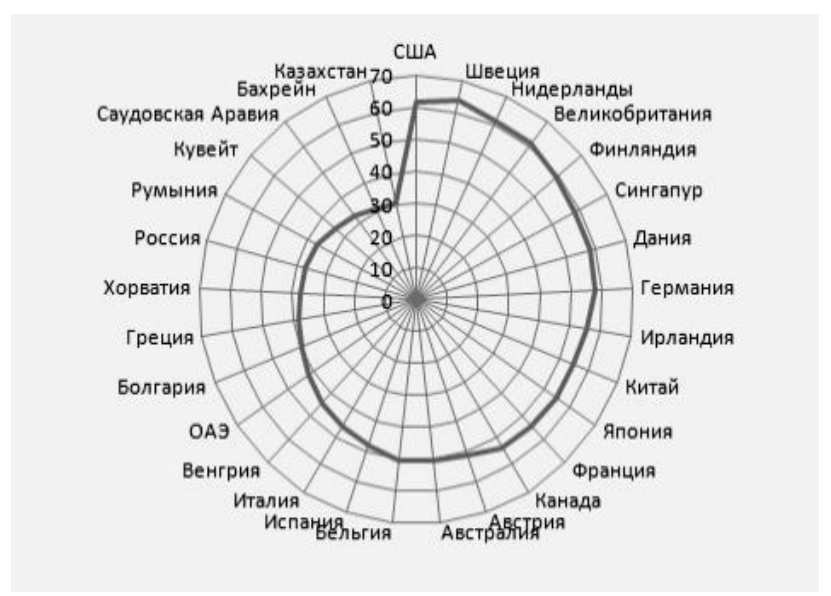

Puc. 1. Дифференциация стран по уровню глобального инновационного индекса.

Построено авторами по источнику https:/www.imd.org/wcc/world-competitiveness-center-rankings/world-digitalcompetitiveness-rankings-2019/ 


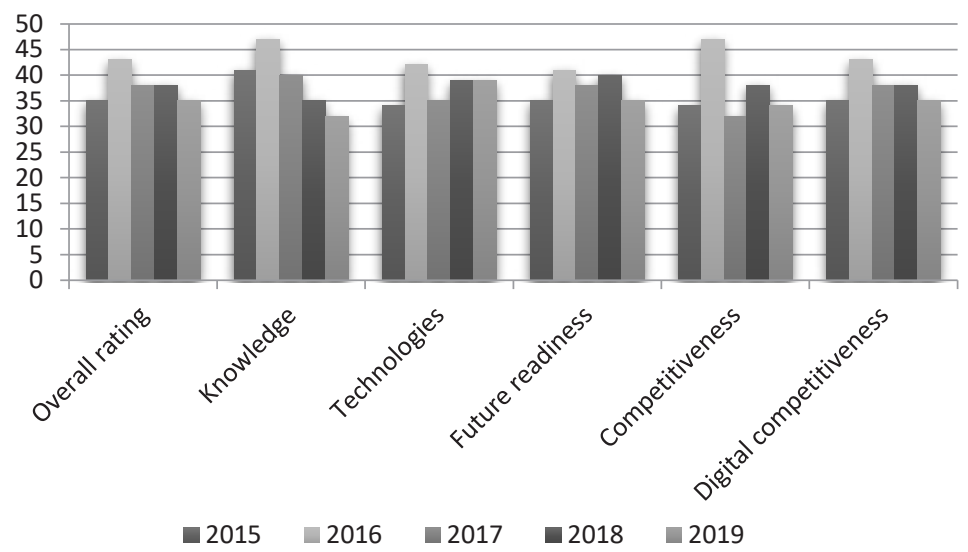

Puc. 2. Динамика рейтинга РК по основным показателями за период 2015 г.-2019 г. Построено авторами по источнику https:/www.imd.org/wcc/world-competitiveness-center-rankings/world-digitalcompetitiveness-rankings-2019/

Оценка динамики рейтинга РК за период 2015 г.-2019 г.позволяет констатировать его снижение в 2019 г. по показателю цифровой конкурентоспособности по сравнению с 2016 г.- 2018 г.

За исследуемый период наблюдается также стабильное снижение рейтинга знаний, что значительно сокращает конкурентоспособность персонала и результативность НИОКР и $\mathrm{R} \& \mathrm{G}$-секторов предприятий.

Специфической особенностью реструктуризации экономики Республики Казахстан сегодня, при превалировании в мировой системе производства высоких технологий и роста объёма информации, является генерирование идей, знаний и компетенций с целью их эффективного использования в оптимизации организационно-управленческой и хозяйственной деятельности предприятий, стимулирования активности инновационной деятельности при переходе от стадии воспроизведения традиционных видов продукции к инновационной стадии - модификации и рационализации инновационной деятельности, обуславливающих увеличение рыночного сегмента и рост конкурентоспособности. Ситуация с наращиванием инновационных преобразований в компаниях НГС РК характеризуется сегодня неготовностью многих предприятий к решительным действиям в этом отношении (рис. 3).

Очевидно, что полный переход на передовые информационные технологии не приветствуется на многих предприятиях отрасли. Наиболее крупные компании НГС РК, такие, как Тенгизшевройл, Карачаганак Петролиум Оперейтинг, НК Казмунайгаз, Мангистаумунайгаз, CNPC-Актюбемунайгаз и др., сегодня реализуют инновации в области финансового анализа и учета добычи нефти и газа (44\% предприя-

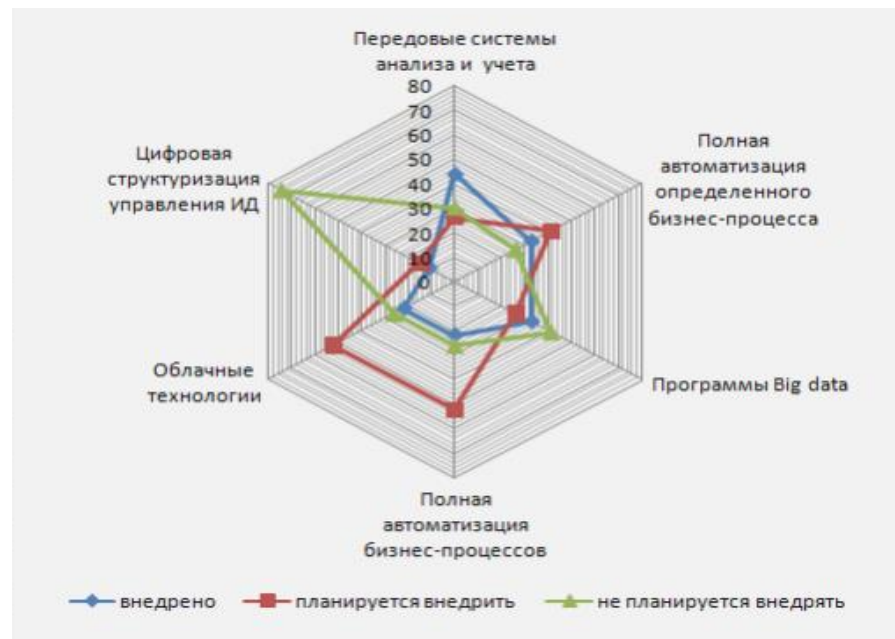

Puc. 3. Готовность предприятий НГС РК к инновационной реструктуризации. Построено авторами по источнику: https://docviewer.yandex.ru/view/28295357/, 2019. 
тий отрасли), в разработке базовых технологий в разведке и добыче (33\%), в автоматизации определенных бизнес-процессов (33\%). Однако организационно-управленческие проблемы решаются в основном привычными, традиционными способами. Цифровая структуризация управления ИД даже не планируется на 74\% компаний отрасли, облачные технологии и программы Big data внедрены соответственно на $22 \%$ и $33 \%$ предприятий, полная автоматизация всех бизнес-процессов внедрена на $22 \%$ предприятий, на $52 \%$ - планируется, и на $26 \%$ отвергается вообще. Программы Big data позволяющие оперативно обрабатывать большие массивы данных и осуществляющие поддержку управленческих решений на основе объективных оценок параметров функционирования предприятий, планируется использовать на $26 \%$ из них и на $41 \%$ отвергаются.

Рост инновационного и цифрового потенциала обеспечивается, в первую очередь, за счет рационального использования собственных ресурсов, внутренних резервов и возможностей предприятий, эффективности топ-менеджмента, обоснованности и актуальности принимаемых управленческих решений. Однако в настоящее время появление новых моделей бизнес-процессов и сетевых структур ориентировано, в основном, на традиционные техникотехнологические решения. Институциональные аспекты цифровой экономики, проблемы развития цифрового потенциала и проблемы развития бизнес-процессов в условиях формирования цифровой экономики остаются пока вне поля зрения управленческих структур компаний, несмотря на задачи, определенные в целевой правительственной Программе «Цифровой Казахстан», утвержденной Постановлением Правительства Республики Казахстан от 12 декабря 2017 года.

Цифровая трансформация промышленности предполагает процесс консолидации бизнес-процессов предприятий и новых компьютерных технологий с целью рационализации инновационной деятельности и повышения конкурентоспособности за счет создания опорных информационно-инновационных платформ и новых бизнес-моделей. Несмотря на актуальность развития креативных секторов экономики, компании НГС не могут представить новые проекты по наращиванию экономической выгоды за счет диверсификации производ- ства. Например, в настоящее время в Казахстане функционирует только три крупных нефтеперерабатывающих завода (Атырауский, Павлодарский, Шымкентский), введённых в эксплуатацию в 1945, 1978 и 1985 годах.

Совершенствование управления инновационной деятельностью компаний нефтегазового сектора РК в настоящее время сопряжено с преодолением ряда проблем, обусловленных отсутствием заинтересованности руководства компаний в инновациях, в том числе и организационно-управленческих; недостатком системности в мониторинге и комплексном анализе конъюнктуры рынка и позиции предприятии на нем; отсутствием четко отлаженного механизма управления ИД.

Вопросы управления инновационной деятельностью рассматривались в трудах многих отечественных и зарубежных исследователей, авторы которых, как правило, акцентировали внимание на стандартных факторах инновационно-технологического развития: внедрение наукоемких технологий, соответствующих технологическому укладу; создание развитой инфраструктуры; открытость и взаимодействие национальной экономики с глобальной мировой экономикой; поддержка свободных зон и зон с опережающим развитием; установление льгот для инновационной деятельности малого и среднего бизнеса, высокотехнологичных производств; ориентация производителей на потребительские интересы и стимулирование непрерывного создания инноваций за счет реформ на законодательном уровне; усовершенствование законодательства, определяющее права на интеллектуальную деятельность.

Несмотря на большое количество научных публикаций по рассматриваемым проблемам, можно констатировать, что актуальные вопросы организационно-управленческого характера, направленные на совершенствование управления инновационной деятельностью компаний нефтегазового сектора Республики Казахстан нуждаются в модификации. В связи с этим представляется своевременной разработка теоретических и практических рекомендаций в данной области исследований для катализации эффективного технологического, экономического и инновационного развития компаний нефтегазового сектора.

Целью данного исследования является разработка рекомендаций и мер по повы- 
шению эффективности управления инновационной деятельностью КНГС Республики Казахстан, их конкурентоспособности и инновационного потенциала на основе применения информационно-аналитических методов и проактивных технологий.

\section{Обзор литературы}

Руководство республики Казахстан неоднократно акцентировало внимание на проблемах ускорения темпов развития профессионализма персонала, инновационной активности, увеличения доли креативных секторов, как в личных выступлениях, так и в государственных постановлениях и программах Республики:

- Послание Президента Республики Казахстан Н. Назарбаева народу Казахстана.

- «Стратегия «Казахстан-2030» на Новом этапе развития Казахстана», февраль, 2007 г.;

- Проект «Интеллектуальная нация-2020», Н.А. Назарбаев, 14 октября 2009 г.;

- Послание Президента от 29 января 2010 г., Н. А. Назарбаев;

- Государственная программа индустриально-инновационного развития Республики Казахстан, утверждена Указом Президента Республики Казахстан № 874 от 1 августа 2014 г.

- Программа «Цифровой Казахстан», утверждена Постановлением Правительства Республики Казахстан от 12 декабря 2017 года № 827.

Ключевая роль в современной экономике отводится инновационным формам хозяйствования, основанным на знаниях и компетенциях, способствующих кардинальной модификации производства и росту производительности (Блок, 2016: 62).

Революционная трансформация организационно-управленческих структур современных компаний, основанная на росте роли высококвалифицированных профессионалов, обладающих управленческими, аналитическими, исследовательскими качествами и представляющими собой творческий интеллектуальный ресурс компании, анализируется с различных точек зрения в работах Д.Тапскотта [Тапскотт, 1999], Т. Малоуна и Р. Лаубахера [Malone, Laubacher, 1998; Малоун, 2006], Л. Эдвинссона и М. Мэлоуна [Эдвинссон, Мэлоун, 1999, с. 442-443].

Но проблема управления индустриальноинновационным развитием промышленных отраслей, а вместе с этим и конкурентоспособностью предприятий, является комплексной задачей, успех решения которой зависит как от качества человеческого капитала, так и от совершенства организационно-управленческих структур и методологических аспектов управления, повышающих его эффективность.

Исследования в области управления инновациями нашли свое отражение в трудах ученых Республики Казахстан: Н.К. Мамырова, Ж. М. Адилова， Ж.Я.Аубакировой， А.Н.Дауренбековой, Ж.Х.Давильбековой, Г.Демисинова, Т.Н.Рогачевой, Е.К.Садыкова, Г.Н.Сансызбаевой, А.Н.Сахановой, Н.П. Сохатской, Г.Султанбековой, М.Д. Тинасилова, В.А.Хан, и ряда др.

Особенности управления инновациями в нефтегазовом секторе экономики рассмотрены в исследованиях Ж.Ж.Адиловой, А.С.Баймуканова, И.Е.Егорова, О.И.Егорова, А.А.Ералиева, Р.Б.Жумагулова， Т.С.Куандыкова， Ю.Л.Кислякова, Д. Коршунова, О.А. Чигаркиной, М. З. Хопабаева и др.

Прикладные аспекты инновационной экономики нефтегазового комплекса рассматривались в трудах зарубежных ученых, таких как М.Адельман, А.Ф.Андреев, Р.Боки, А.С.Винницкий, В.С.Грайфер, И.А.Жученко, А. Кемп, А.И.Ковалева, А.А.Конопляник, Б.С.Лазарян, С.Макдональд, А.Мартин, Д.Мосс, И.Моран, А.И.Шпильман и отечественных авторов: О. И. Егорова, А.А. Жалгасбаевой, А. У. Искаковой, Э.Т. Машенбаевой, Ч.М. Сейсекенова, Ж.У.Сулейменовой и др.

Вопросы управления инновационной деятельностью предприятий рассмотрены в трудах российских исследователей: О.М.Белоцерковского, С.Ю.Глазьева, М.А. Гершмана, Н.Д. Кондратьева, Б.Л.Кузнецова, Ю.Г.Лавриковой, И.Н.Насырова, О.А. Романовой, О.С. Сухарева, А.И. Татаркина и др.

В работах Брауна (Браун, 2017) и Крафке (Крафке, 2018) отмечается роль инноваций в развитии бизнеса, позволяющих оптимизировать соотношение прибыль - затраты, и финансовых инвестиций, недостаток которых сдерживает возможности предприятий в этом аспекте.

Таким образом, в литературе достаточно полно освещены вопросы теории, прикладные аспекты, методологии управления, оценки внутренних ресурсов и возможности реализациии инновационной деятельности предприятий, в том числе и НГС, рассмотрены проблемы реализации инновационного процесса в современной промышленности РК. В то же время следует от- 
метить, что недостаточно внимания уделяется оптимизации функций управления инновациями, рационализации и структуризации самого процесса управления ИД, логической взаимосвязи бизнес-функций ИД. Решению данных вопросов уделяется внимание в настоящей работе.

\section{Методология}

Настоящее исследование включало методы системного и статистического анализа данных, технологии функционального моделирования IDEF0, которые в совокупности позволили идентифицировать сущность исследуемой проблемы.

Рассматривая проблему управления инновационной деятельностью КНГС РК, следует учитывать современные методологические тренды, гарантирующие системность и объективность в обосновании принимаемых управленческих решений, а также эффективность экономической деятельности компаний в условиях сложившейся рыночной конъюнктуры.

Портфельный анализ инновационной деятельности КНГС, к которым относятся «Тенгизшевройл», «Карачаганак Петролеум Оперейтинг Б. В.» Казахстанский филиал, «Мангистаумунайгаз», «Озенмунайгаз», «СНПС-Актобемунайгаз», «Эмбамунайгаз», «Каражанбасмунай», «Совместное предприятие «Казгермунай», Филиал «НортКаспианОперейтинг Компани Н.В.», «АджипКарачаганак Б.В.», Филиал «Би Джи Карачаганак Лимитед (Аксай)», «Каспий нефть», «ПетроКазахстанКумкольРесорсиз», Филиал «Шеврон Интернэшнл Петролеум Компани», «Матен Петролеум», Филиал «ЛУКОЙЛ
Оверсиз Карачаганак Б.В.», «КазТрансОйл», позволяет обосновать приоритеты инновационного развития, исходя из объективной оценки реалий сегодняшнего дня (рис. 4).

Очевидно, что большинство из представленных на рисунке 4 предприятий (2 и 4-17) находятся в стадии завоевания рынка (сектор «Вопросительные знаки») и характеризуются невысокой относительной его долей и низкой прибыльностью (её определяет размер кружков). Исключением являются предприятия 2,7,4 (с высоким темпом роста рынка) и 7 (с высоким уровнем прибыли). Без интенсификации усилий по увеличению рыночной доли и темпов роста рынка, развития креативных секторов, грамотного управления и значительных инвестиций они рискуют перейти в стадию спада («Мертвый груз») или уйти с рынка вообще. Предприятия 1 и 3 попадают в сектор «Звезды» и характеризуются стадией роста, но, несмотря на высокую относительную долю рынка, рискуют попасть в сектор «Денежные мешки» - сектор застойного производства с низким уровнем инновационной активности. Стратегия организационноуправленческих воздействий на этих предприятиях должна формироваться на основе создания креативных секторов, повышения качества управления и грамотного инвестирования. Для сохранения лидерства им необходимо селективное развитие на основе интенсификации усилий по сохранению и упрочению достигнутых позиций.

Инновационное реструктурирование КНГС предполагает переход от развития, в основе

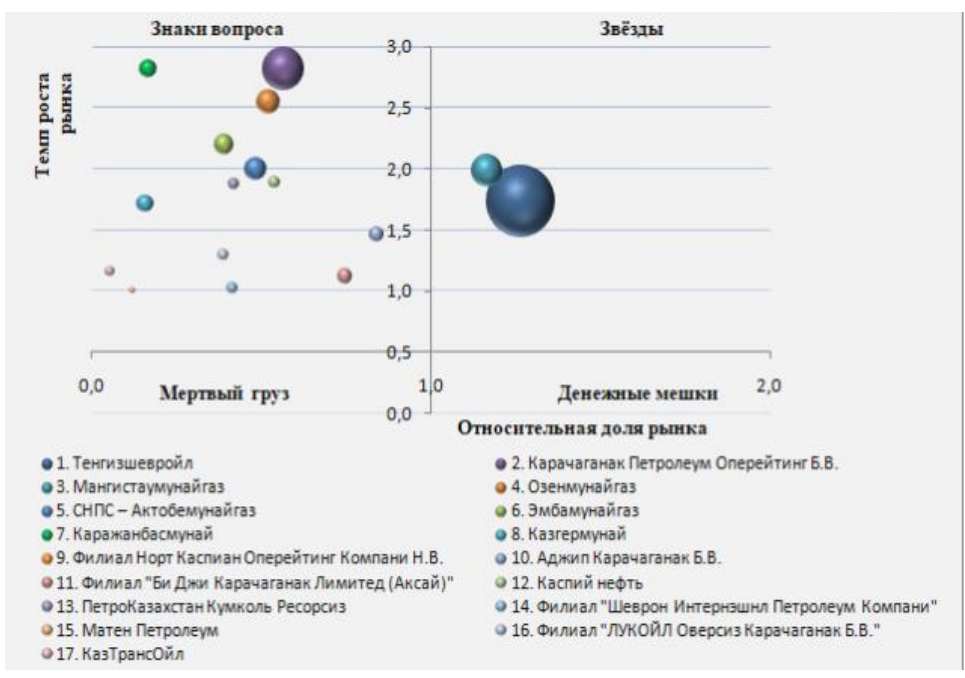

Puc. 4. Анализ деятельности КНГС РК на основе матрицы ВСG

Построено авторами по источнику https://www.lsm.kz/top-100 
которого лежит использование природных ресурсов, к развитию, базирующемуся на эксплуатации человеческого интеллекта, разработке и внедрению наукоемких технологий, креативных секторов и фундаментальных открытий. Поэтому особое значение имеет сохранение и наращивание человеческого потенциала, способного эффективно адаптироваться к уплотнению потока нововведений. Существующие на ряде предприятий проблемы повышения уровня профессионализма персонала (некомпетентность административного аппарата, отсутствие материальных последствий за формализм и интуитивный подход к принятию решений, недостаточная квалификация рядовых работников, отсутствие у последних заинтересованности в повышении эффективности производства) сдерживают их прогрессивное развитие.

Таким образом, среди приоритетных направлений индустриально-инновационного развития КНГС - совершенствование управления на основе современных информационно-аналитических методологий. Основой управления любым процессом в экономике является решение, а качество и эффективность управленческого решения во многом определяется применяемой технологией его разработки и обоснования. Схема совершенствования процесса управления инновационной деятельностью КНГС в этом аспекте может быть представлена в следующем виде (рис. 5).

Формализация и структурирование направлены на создание гибкой системы управления процессом развития ИД, ориентированной на оценку положения компании в отрасли, её экономические и ресурсные возможности.

Авторская концепция совершенствования процесса управления ИД компаний НГС нашла отражение в разработанной модели его эффективного развития, представленной в нотации IDEF0(TO-BE). Модель отображает логические отношения и взаимосвязи между функциональными блоками в последовательности реализации этапов ИД в соответствии с методологией структурного анализа Structured Analysis and
Design Technique (SADT) (рис. 6).

Цель модели - наглядно описать иерархически упорядоченную логическую последовательность функций ИД, обеспечивающую формализацию и структурирование процесса управления ИД на основе графического моделирования.

Функциональная модель состоит из блоков, сопровождающихся входами, выходами, управлением и механизмами, необходимыми для проведения исследования, оценки и реализации выполняемых функций. При этом под входами подразумеваются объекты, воздействующие на выполнение функции; под выходами - результаты выполнения функций; под управлением нормативные и институциональные критерии, регламентирующие выполнение функций; под механизмами - используемые ресурсы.

Утверждение приоритетных факторов развития ИД НГК РК, отвечающих, законам и принципам управления экономическими системами, состоянию институциональной среды и требованиям государственных и международных стандартов, является результатом анализа состояния и проблем в управлении инновационной деятельностью КНГС РК, выполняемого в первом блоке модели. Функции второго блока по формированию стратегии, ориентированной на развитие приоритетных факторов развития ИД КНГС РК в соответствии с отраслевыми особенностями, способствуют генерации знаний и компетенций персонала, играющих определяющую роль в модернизации деятельности компаний НГС РК и направленных на создание концепции развития ИД КНГС РК и её реализацию (блок 3).

Спецификация информационно-аналитической модели, на создание и исследование которой направлены функции четвертого блока, предназначена для оптимизации и рационализации процесса управления ИД КНГС и разработки рекомендаций по его совершенствованию.

Результаты выполнения каждой функции блоков обеспечиваются предварительным качественно-количественным анализом, который основан на применении бизнес-аналитики и

\begin{tabular}{|c|c|c|c|}
\hline $\begin{array}{l}\text { Формализация и } \\
\text { структурирование } \\
\text { процесса управления ИД }\end{array}$ & $\begin{array}{c}\text { Моделирование и анализ } \\
\text { процесса управления ИД } \\
\text { по критериям КРI }\end{array}$ & $\begin{array}{l}\text { Выбор инструментария } \\
\text { и разработка плана } \\
\text { совершенствования } \\
\text { процесса управления ИД }\end{array}$ & $\begin{array}{l}\text { Контроль исполнения } \\
\text { мероприятий плана по } \\
\text { совершенствованию } \\
\text { процесса управления ИД }\end{array}$ \\
\hline
\end{tabular}

Puc. 5. Схема совершенствования процесса управления ИД Построено авторами 


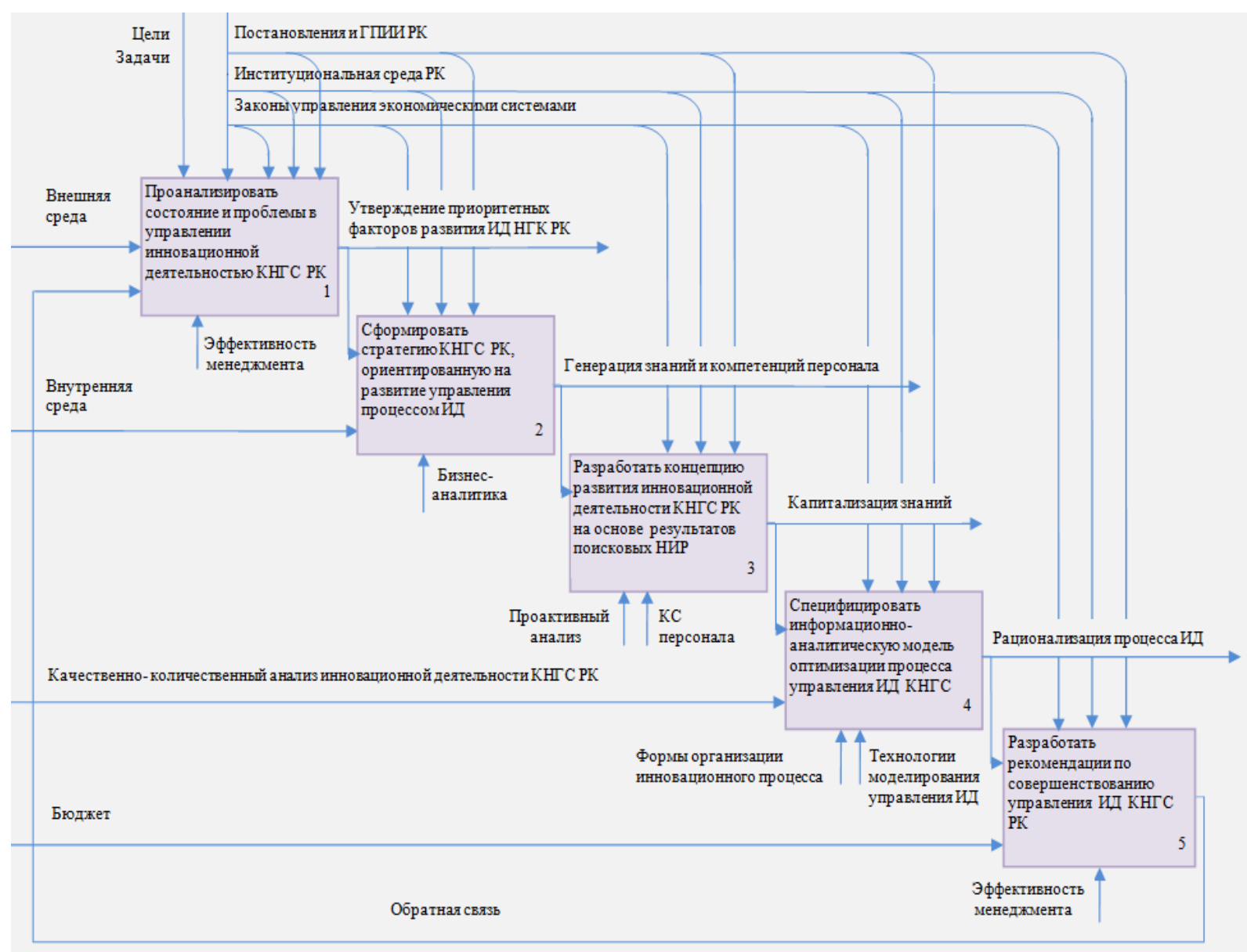

Puc. 6. Модель совершенствования процесса управления ИД компаний НГС в нотации IDEF0 Построено авторами

проактивных технологий, позволяющих оценить перспективы внедрения инноваций посредством оценок факторов развития отраслевого рынка и экономической эффективности применяемых компанией и планируемых к применению технологий для освоения приоритетных видов сырья. Отметим, что принятие оптимальных решений при постоянно меняющихся условиях внешней среды в соответствии с результатами моделирования обуславливается доступностью информации о рисках и возможных будущих проблемах заблаговременно, до того как они возникнут.

Проактивные технологии относятся к наиболее актуальным в этом отношении методам исследования, обеспечивающим направленность производственных процессов на упреждающее развитие. Методы, применяемые в процессе проактивного анализа, относятся к приемам стратегического анализа сценариев инновационного развития предприятия. К ним отно- сится метод портфельного анализа - матрица BCG, матрица McKinsey, матрица Hofer/Schendel, матрица ADL/LC, ABC-XYZ- анализ и др. Разработанная модель направлена на оптимизацию инновационной стратегии и рационализацию ИД, основываясь на применении современных технологий и форм организации инновационного процесса, на генерации знаний и умений персонала и эффективности менеджмента.

\section{Результаты и обсуждение}

Представленная модель совершенствования управления ИД доступна для использования и даёт возможность глубокого проникновения в суть исследуемого процесса за счет использования графического языка и структурного анализа SADT. Она основана на применении современных методов информационно-аналитического и проактивного анализа экономической и инновационной деятельности, и в совокупности с цифровыми технологиями удобна для алгорит- 
мизации и проектирования инновационного процесса, построения блокчейнов посредством создания компьютерных программ.

Её использование позволяет создать современную технологию управления ИД, оптимизировать решение ряда её ключевых проблем, повысить конкурентоспособность как компаний, так и персонала всех уровней. Результаты поисковых НИР, расчетов и моделирования позволят руководству компаний обосновывать принятые управленческие решения пол совершенствованию управления ИД КНГС.

\section{Вывод}

Отметим, что создание модели совершенствования процесса управления ИД подчинено ряду регламентирующих условий, определённых Постановлениями правительства Республики Казахстан, ГПИИР, институциональной средой Республики, а также принципами и законами управления экономическими системами. Распределение рисков должно носить компромиссный характер, что вызывает необходимость развития рынка страхования и поддержку правительства.

Главной целью совершенствования управления инновационной деятельностью КНГС РК является обеспечение конкурентоспособности предприятия на каждом этапе жизненного цикла инновационного проекта за счет коммерциализации и повышения рентабельности и окупаемости научных разработок и создания наукоемких продуктов и креативных секторов. Достижение данной цели требует решения следующих задач:

- изучение и формирование методологии и методики отбора инновационных разработок;

- совершенствование организационноуправленческих структур управления ИД;
- создание системы кадрового обеспечения инновационной деятельности;

- обеспечение информационно-аналитической поддержки управления ИД компаний НГС $\mathrm{PK}$;

- генерацию знаний и компетенций персонала;

- капитализацию знаний;

- анализ приоритетных направлений исследований и разработок;

- разработку методов стимулирования инновационной деятельности;

- формирование инфраструктуры инновационной деятельности.

Обобщая результаты настоящего исследования, отметим, что в работе предложены меры стратегического анализа деятельности КНГС РК и ИД, позволяющие прогнозировать развитие компаний, исходя из их текущего состояния на отраслевом рынке, элиминируя рисковые ситуации в будущем. Приведены рекомендации по повышению эффективности управления инновационной деятельностью КНГС, а также построена модель, позволяющая руководству компаний исключить интуитивное суждение о направлениях инновационного развития путём информационно-аналитического обоснования решений; разработана технология рационального организационно-экономического управления инновационной деятельностью КНГС РК, основанная на формализации и структурировании инновационного процесса.

Задача КНГС РК - обеспечить поддержку такого состояния уровня инновационной деятельности, которое создаст условия для модернизации технико-технологических и организационно-управленческих структур, нацеленных на опережающее развитие компаний отрасли и вхождение их в лидеры мировой экономики.

\section{Библиографический список}

1 Address by the President of the Republic of Kazakhstan, Leader of the Nation, N. Nazarbayev «Strategy Kazakhstan-2050»: new political course of the established state». 14.02.2012.

2 Baumol W. The free-market innovation machine: Analyzing the Growth Miracle of Capitalism. Princeton: Princeton University Press. - 2002, 307 p.

3 Blackburn R., Kovalainen A. (2008) Researching small firms and entrepreneurship: Past, present and future // International Journal of Management Reviews. P. 1-21.

4 Block J., Fisch C., van Praag C.M. The Schumpeterian entrepreneur: A review of the empirical evidence on the antecedents, behavior, and consequences of innovative entrepreneurship // Industry \& Innovation. - 2016. - vol. 24.- no. 1, pp. 61-95.

5 Brown J.D., Earle J. S. Finance and growth at the firm level: evidence from SBA loans. IZA Discussion Paper No9267.2015. 
6 Cocca P., Alberti M. A framework to assess performance measurement systems in SMEs // International Journal of Productivity and Performance Management. - 2010. - vol. 59(2), pp. 186-200.

7 Edwards T., Delbridge R., Munday M. Understanding innovation in small and medium-sized enterprises: a process manifest // Technovation. - 2005. - No25(1), pp. 1119-1127, https://doi.org/10.1016/j.technovation.2004.04.005

8 Foroudi P., Jin Zhongqi, Gupta Suraksha, Melewar T.C., Foroudi M.M. Influence of innovation capability and customer experience on reputation and loyalty // Journal of Business Research._ Elsevier._ 2016._ vol. 69(11), pp. 4882-4889.

9 Foss N., Saebi T. Business models for open innovation: Matching heterogeneous open innovation strategies with business model dimensions // European Management Journal._ 2015._-vol. 33(3), pp. 201-213.

10 Hoq M.Z., Ha N. C. Innovativeness: its antecedents and relationship to SME business performance / Proceedings of AN-ZMAC 2009 Conference. Australian \& New Zealand.- Marketing Academy.- Melbourne, Australia. - 2009, https://doi.org/10.2139/ssrn.1851423.

11 IMD WORLD COMPETITIVENESS CENTER, Digital Competitiveness Ranking. https://www.imd.org/wcc/worldcompetitiveness-center-rankings/profiles -factors/

12 Klafke R., Zhuparova D., Zhaisanova A. Key features of innovative development of smes in the republic of Kazakhstan // The Journal of Economic Research \& Business Administration._ 2018.- vol. 125(3), pp. 139-146, http://be.kaznu.kz/index.php/math/article/view/2228

13 Matejun $M$. The effect of innovation potential on small business performance // PEOPLE: International Journal of Social Sciences. - 2017. - vol. 3. - no.1, pp. 80-100, https://dx.doi.org/10.20319/pijss.2017.31.80100

14 Manjon J., Mompo R., Redoli J. Accelerating Innovation in Small and Medium-sized Enterprises in the ICT Services Sector // SAGE Open.- 2016

15 Maravelakis E., Bilalis N., Antoniadis A., Jones K. A., Moustakis V. Measuring and benchmarking the innovativeness of SMEs: A three-dimensional fuzzy logic approach // Production Planning \& Control._- 2006._ vol. 17(3), pp. 283-292, https://doi.org/10.1080/09537280500285532

16 Malone T.W., Laubacher J. (1998) The dawn of the e-lance economy // Harvard Business Review. V. 76. № . 5. P. 144-153.

17 Official site of the Committee on Statistics of the Ministry of National Economy of the Republic of Kazakhstan.2018, http://www.stat.gov.kz

18 Orlova, L.V., Sakhabieva, G.A., Pronina, N.N., Vasyaycheva, V.A. Impact of Educational Attainment on the Development of Female Entrepreneurship in Kazakhstan // Indian Journal of Science and Technology.. - 2016.V. 9, Iss. 11. P. 89426-89433.

19 Sheko, P. Innovative economic mechanism //Problems of management theory and practice. - 1999.- No.2. P.7178.

20 Тапскотт Д. (1999) Электронно-цифровое общество. Пер. с англ. Киев: INT-press. М.: Рефл бук.

21 Эдвинссон Л., Мэлоун М. (1999) Интеллектуальный капитал. Определение истинной стоимости компании // Новая постиндустриальная волна на Западе. Антология / Под. ред. В. Л. Иноземцева. М.: Аcademia.. - 1999.С. 429-447.

22 Васяйчева В.А.Теоретико-методические вопросы управления конкурентоспособностью промышленных предприятий: монография.-Самара: Изд-во «Самарский университет. - 2016. - 160 с.

23 Хопабаев М. З. Активизация индустриально-инновационного развития нефтегазового сектора Республики Казахстан: приоритеты и механизмы совершенствования (на примере Мангистауской области) //автореферат дис. /Алматы - 2010.-44с.

24 Сейсекенов, Ч.М. Пути повышения эффективности иностранных инвестиций в нефтегазовой отрасли: мировой опыт и практика Казахстана // автореферат дис. / Сейсекенов, Ч.M.- Алматы: LEM, 2006. - 30 с. -

25 Сулейменова М.Ж., Панкина К., Куанышева А. КАЗАХСТАНСКАЯ ЭКОНОМИЧЕСКАЯ МОДЕЛЬ РАЗВИТИЯ // Международный журнал прикладных и фундаментальных исследований. - 2016. - № 7-3. - С. 461-464. 